\title{
Mechanisms in hypertension and target organ damage: Is the role of the thymus key? (Review)
}

\author{
XIANLIANG DAI*, LI HUA*, YIHONG CHEN*, JIAMEI WANG, JINGYI LI, FENG WU, \\ YANDA ZHANG, JIYUAN SU, ZONGGUI WU and CHUN LIANG
}

Department of Cardiology, Changzheng Hospital, Second Military Medical University, Shanghai 200003, P.R. China

Received October 27, 2017; Accepted March 27, 2018

DOI: $10.3892 / \mathrm{ijmm} .2018 .3605$

\begin{abstract}
A variety of cells and cytokines have been shown to be involved in the whole process of hypertension. Data from experimental and clinical studies on hypertension have confirmed the key roles of immune cells and inflammation in the process. Dysfunction of the thymus, which modulates the development and maturation of lymphocytes, has been shown to be associated with the severity of hypertension. Furthermore, gradual atrophy, functional decline or loss of the thymus has been revealed to be associated with aging. The restoration or enhancement of thymus function via upregulation in the expression of thymus transcription factors forkhead box N1 or thymus transplantation may provide an option to halt or reverse the pathological process of hypertension. Therefore, the thymus may be key in hypertension and associated target organ damage, and may provide a novel treatment strategy for the clinical management of patients with hypertension in addition to different commercial drugs. The purpose of this review is to summarize and discuss the advances in our understanding of the impact of thymus function on hypertension from data from animal and human studies, and the potential mechanisms.
\end{abstract}

\section{Contents}

1. Introduction

2. Potential role of the thymus in hypertension

3. Aging, thymosin $\beta 4$ and hypertension

4. Conclusion and prospects

Correspondence to: Professor Chun Liang or Professor Zonggui $\mathrm{Wu}$, Department of Cardiology, Changzheng Hospital, Second Military Medical University, 415 Fengyang Road, Shanghai 200003, P.R. China

E-mail: chunliang@smmu.edu.cn

E-mail: zongguiwu@smmu.edu.cn

*Contributed equally

Key words: hypertension, aging, immunity, thymus, transplantation, forkhead box N1

\section{Introduction}

Hypertension is characterized by the elevation of arterial pressure, and can be complicated by damage and metabolic changes in the heart, blood vessels, brain, kidney, retina and other target organs. It is a multifactorial disease and various immune cells and factors have been shown to be involved (Fig. 1) (1). There have been increases in the incidence and mortality rates of patients with heart and cerebrovascular disease; therefore, reducing the incidence and mortality rates of heart and cerebrovascular disease in patients with hypertension is the ultimate goal of antihypertensive therapy. However, even when blood pressure is under control, organ damage and abnormal metabolism may not be completely resolved, which suggests that other mechanisms may be involved in, or contribute to, the complex pathological processes of hypertension and may not be eliminated by current drug strategies. Antihypertensive therapy requires the establishment of blood pressure control (2). Therefore, it is of clinical and practical significance to investigate the mechanism of hypertension.

The thymus, as a key organ in T lymphocyte ontogenesis, has been shown to be crucial in optimizing immune system function throughout life (3-7), therefore, the pathological processes of high blood pressure are considered to be closely associated with the thymus. Studies have revealed that the thymus exhibits constant atrophy or hypofunction with age (8). Fukuda et al (9) suggested that the values of thymus weights were lower in Spontaneously hypertensive rats (SHR), compared with those in Wistar Kyoto (WKY) rats, when they investigated age-related changing in hematological values, serum biochemical constituents, and weights of various organs in both genders of SHR/Izm, Stroke-prone SHR and WKY/Izm rat strains. A previous study by Svendsen et al found that the salt-dependent phase of deoxycorticosterone acetate salt hypertension did not develop and the decreased perivascular infiltration of immune cells following renal infarction was not present in athymic 'nude' mice. However, if the thymus gland was transplanted into these athymic mice, then the capacity for developing salt-driven hypertension was restored (10-13). Ba et al showed that the thymus transplanted from neonatal normotensive Wistar rats to the prehypertensive SHR strain delayed the onset of hypertension from 5 to 32 weeks and decreased blood pressure in hypertensive adults; it is known that the SHR strain has normal blood pressure at birth and 
gradually develops high blood pressure from $\sim 5$ weeks of age, reaching maximal levels at $\sim 15-20$ weeks of age (14). Therefore, the thymus may be involved in the process of hypertension. However, the mechanism of thymus function in the process of hypertension remains to be fully elucidated. The purpose of this review was to summarize and discuss advances in our knowledge of hypertensive vascular disease by the effect of thymus function on hypertension, with a particular focus on the mechanism underlying the effect of thymus function on hypertension.

\section{Potential role of the thymus in hypertension}

Thymus function and inflammatory procedure. The thymus is known to be essential in $\mathrm{T}$ cell development and maturation. The thymus is where the $\mathrm{T}$ cell repertoire is generated, and where $\mathrm{T}$ cells undergo positive and negative selection, leading to a wide functional MHC-restricted naïve T cell receptor $\alpha \beta$ repertoire $(15,16)$. In the development of $\mathrm{T}$ cells, they migrate within distinct thymus microenvironments, where they interact with stromal cells to provide signals crucial to the survival, proliferation, differentiation and selection of thymocytes (17-19). Naïve T cells can differentiate into helper $\mathrm{T}$ cells $(\mathrm{Th})$, regulatory $\mathrm{T}$ cells (Tregs) and cytotoxic $\mathrm{T}$ cells. The generation and maturation of the specific $\mathrm{T}$ cell lineage involves specific and complex processes within the thymus, and several signaling pathways are involved in these processes. If thymocytes respond spontaneously to these antigens, they undergo negative selection, through apoptosis, or into Treg lineages (17). It is now well established that Tregs are produced via two main pathways in vivo. The majority of functionally mature Treg cells are produced in the thymus, where recognition of self-antigen by certain clones leads to their deviation into the thymus-derived forkhead box (Fox)p $3^{+}$Treg cell lineage $(20,21)$. Th cells can secrete interleukin (IL)-4, IL-17 and interferon (IFN) $-\gamma$. In addition, Tregs can secrete IL-10. IL-4 regulates the proliferation of activated B-cells and mast cells (22-25). In the absence of vascular tissue, the presence of IL4 promotes the substitution of activated macrophages into M2 cells and inhibits the activation of classical activated macrophage M1 cells. Increased macrophage repair (M2) combined with the secretion of IL-10 and transforming growth factor (TGF)- $\beta$ results in a reduction of pathological inflammation (26-28). IL-17 is involved in the induction and regulation of pro-inflammatory responses. IL-17 induces the production of other cytokines, [IL-6, TGF- $\beta$, tumor necrosis factor (TNF)- $\alpha$, granulocyte colony-stimulating factor, granulocyte-macrophage colony-stimulating factor and IL-1 $\beta$, chemokines (IL-8, growth regulated oncogene- $\alpha$ and monocyte chemoattractant protein-1), and prostaglandin, including prostaglandin E2, from fibroblasts, endothelial cells and several other cell types (29-33). All of these cytokines, chemokines and inflammatory cells are involved in the inflammatory procedure $(34,35)$. By contrast, these factors and cytokines also promote the inflammatory response. Therefore, changes in thymus function can affect the inflammatory response.

Low-grade inflammation has been shown to be crucial in the pathogenesis of hypertension and involved in several processes that promote the development of blood pressure (36-39). Inflammatory factors in the process of inflammation can

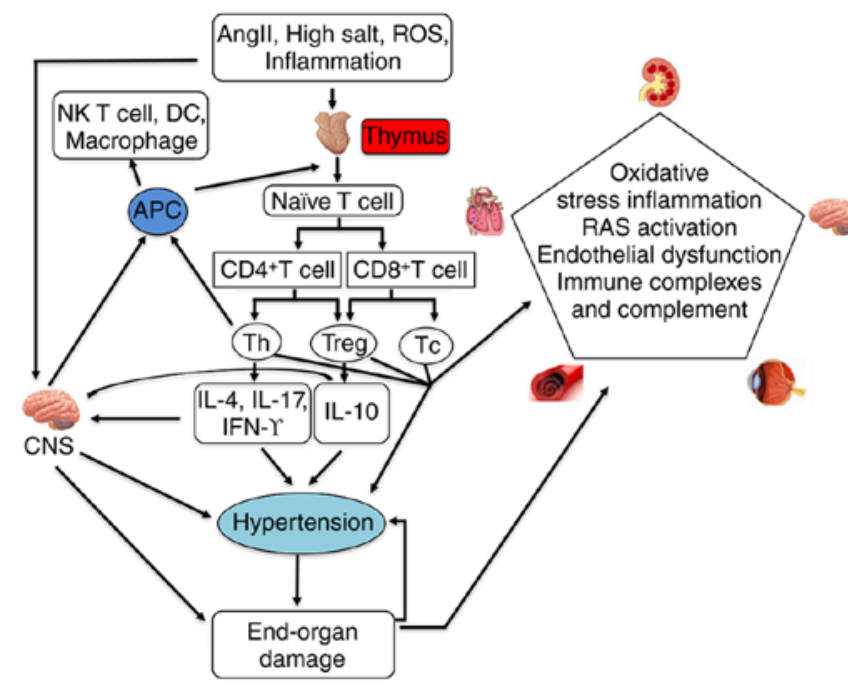

Figure 1. Factors involved in hypertension. Various types of cells and cytokines and the autonomic nervous system are affected by thymus function, and may be involved in the process of hypertension and target organ damage. Ang II, angiotensin II; ROS, reactive oxygen species; NK, natural killer T cell; DC, dendritic cell; APC, antigen-presenting cell; Th, Thelper; Treg, regulatory T cell; Tc, cytotoxic T cell; IL, interleukin; IFN, interferon; CNS, central nervous system; Ras, renin-angiotensin system.

cause endothelial damage and activate the renin system, and studies have demonstrated that activation of the intrarenal renin-angiotensin system (RAS) and endothelial dysfunction are important in the development of hypertension (40-42). Nitric oxide (NO) and superoxide may cause endothelial dysfunction in hypertension, and the balance between them may be more important than the absolute levels of either alone $(43,44)$. Other cross-sectional studies have shown a correlation between C-reactive protein (CRP), TNF and IL-6 and essential hypertension (37,45-47). Elevation of the serum concentrations of CRP and cytokines demonstrates that low-grade inflammation is present in hypertension $(48,49)$. The association between CRP and systemic hypertension has been established in multiple cross-sectional studies, particularly following the emergence of the high sensitivity CRP assays capable of detecting levels that were earlier considered to be normal (39,50-54). Higher levels of CRP may contribute to the development of systemic hypertension by reducing the production of NO in endothelial cells, increasing the production of endothelin 1 and leading to vasoconstriction (39,55-57).

Evidence suggests that oxidative stress and angiotensin II (Ang II) are critical in the pathogenesis of hypertension and vascular endothelial dysfunction $(43,44,58)$. Studies have shown that Ang II induces severe inflammation and activates redox-sensitive genes via the activation of nuclear factor (NF) $-\kappa \mathrm{B}$, independent of blood pressure in double transgenic rats harboring human renin and human angiotensinogen genes $(43,59-61)$. It is well known that these cells, inflammatory factors and oxidative stress are involved in the process of target organ damage, as mentioned above (62-64). The thymus may be involved in the process of hypertension and target organ damage by regulating the inflammatory reaction.

Thymus function and the immune system. In 1970, Ebringer and Doyle found that serum immunoglobulin levels were 
significantly increased in $30 \%$ of patients with hypertension, and with the rapid development of clinical immunology, increasing evidence has shown that hypertension is always accompanied with immune dysfunction and there are immune factors involved in the complications of hypertension (65-67). Several studies have shown that, in hypertension, T cells can cause high blood pressure, vascular disorders and kidney disease, and the possible mechanisms include the release of cytokines directly affecting vascular and renal function or indirectly stimulating cells to release cytokines (68). The thymus is an important and essential site for the generation and maturation of $\mathrm{T}$ cells in vivo, as this microenvironment induces and supports lineage commitment, differentiation and the survival of thymus-seeding cells.

$\mathrm{T}$ cells and their subsets are involved, either directly or through the secretion of certain factors, in the process of hypertension. The selection of one of the $\mathrm{T}$ cells subsets, Tregs, in the thymus is essential for preventing autoimmune diseases (69). Tregs of the $\mathrm{CD} 4^{+} \mathrm{CD} 25^{+} \mathrm{FOXP} 3^{+}$phenotype are generated in the thymus, and are critical for the maintenance of immune homeostasis and the suppression of naturally occurring self-reactive T cells (70-72). Previously, it was shown that changes in the immune system are important in the SHR model and other models of hypertension; $T$ cell activation and vascular inflammation may contribute to the formation of high blood pressure (48,73-76).

There is emerging evidence suggesting that the immune response is significant in the pathogenesis of hypertension (77-79). The classical immune system is considered to consist of two parts: Innate and adaptive immunity (77,80-82). Innate immune responses mediated by macrophages are triggered through toll-like receptors. In animal models of hypertension, the infiltration of inflammatory cells from the innate immune system, including dendritic cells (DCs), natural killer cells and predominantly monocytes/macrophages has been documented in the perivascular fat and adventitia of blood vessels, and in target organs including the kidney and heart $(77,83)$. Various studies have suggested a role for macrophages in the pathogenesis of hypertension and vascular damage (84-87). Macrophages generate superoxide when NADPH oxidase is activated by Ang II or mineralocorticoids, and this may lead to vascular wall remodeling and contribute to blood pressure (BP) elevation $(49,88)$. Therefore, the role of monocytes/macrophages has been expanded (89-91).

Adaptive immune responses are characterized by activated lymphocytes, and interact with innate immunity in the pathophysiology of cardiovascular disease and hypertension (92-94). Several studies have confirmed that $\mathrm{T}$ cells and their subsets, including effector $\mathrm{T}$ lymphocytes and Treg cells, are involved in the process of hypertension (95-97). Rodriguez-Iturbe and Johnson (98) showed that T lymphocytes contribute to renal changes and BP elevation in rodents, which others have since confirmed and extended (99). It has been reported that T-effector cells that mediate, in part, the pressor effects of Ang II are predominantly $\mathrm{CD} 8^{+}$rather than $\mathrm{CD}^{+}(100)$. Studies have shown that immune cells are involved in target organ damage caused by hypertension $(63,96)$. Possible mechanisms for their involvement in the process of hypertension have been investigated previously. The change in thymus function can affect the function of macrophages and B cells. The monocyte-macrophage system is crucial in innate immunity and in the initiation of the adaptive immune response (101-103). Plasma cells derived from B cells are involved in the humoral immune response. In addition, DCs are significant in establishing self-tolerance and inducing antigen-specific immunity through their ability to present self-antigens to developing $\mathrm{T}$ cells in the thymus (104-106). Therefore, the thymus may be involved in the process of hypertension via the immune system.

Thymus function and the renal system. Inflammation is associated with several hypertensive models in the kidney, including two-kidney-one-clip hypertension and salt-sensitive hypertension (107). T lymphocytes and macrophages infiltrate the kidneys in various models of hypertension (108-111). Changes of thymus function can also affect the function of macrophages and $\mathrm{T}$ lymphocytes; therefore, changes in thymus function can affect kidney function. The effects of RAS activation on kidney function and its role in hypertension have been investigated extensively (112). Here discusses the role of immune cells, induced by changes in thymus function in the kidney, in hypertension.

As early as 1964, the injection of kidney extract in normal rat hypertension confirmed the role of autoimmunity in the renal infarct model (113). It was observed that the infiltration of immune-cells and increased activity of $\mathrm{NF}-\kappa \mathrm{B}$ in the kidney occurred at a prehypertensive age and progressively increased with age in the SHR model, which was inhibited by a broad-spectrum inhibitor, phyrrolidine dithiocarbamate $(114,115)$. Other studies have shown that hypertension induced by Ang II or high salt can lead to the activation of $\mathrm{T}$ cells and the subsequent entry of activated $\mathrm{T}$ cells into the peripheral blood vessels and kidney $(96,116)$. Studies have also shown that the cells which accumulate in the kidneys and blood vessel release pro-inflammatory cytokines, and promote vasoconstriction and sodium retention, leading to high BP $(64,96,117,118)$.

Yang et al (119) found that modulation of NADPH oxidase-derived oxidative stress and immune cell function via A3 receptor signaling may be critical mechanisms in the development of hypertension and associated target organ damage. Their data showed that these changes in the innate and adaptive immune systems in $\mathrm{A}^{-/-}$mice assisted in eliminating pathological changes in the renal and cardiovascular systems following uninephrectomy-high salt and protected the $\mathrm{A}^{-1-}$ mice from developing hypertension. This finding is consistent with previous studies of the role of $\mathrm{T}$ cells in renal injury and hypertension $(63,120)$.

Thymus function and the autonomic nervous system (ANS). The ANS, which is composed of sympathetic and parasympathetic (vagal) innervation of the heart and predominantly sympathetic innervation of the vascular system, controls and regulates the secretion and activity of various organs, blood vessels, smooth muscles and glands, and is involved in the endocrine regulation of glucose, fat and fluid, electrolyte metabolism, body temperature, sleep and BP $(121,122)$. There is evidence that the ANS is key in regulating the immune system (123-127), and there is substantial evidence that the thymus receives dense sympathetic innervation, which 
originates from postganglionic neurons in the upper paravertebral ganglia of the sympathetic chain, particularly the superior cervical and stellate ganglia (128-131). The importance of the ANS has been recognized to be of main clinical and therapeutic significance in the progression of chronic cardiovascular disease, primarily as a result of changes in the immune system (132-134). Previous studies have shown that thymocytes and thymic epithelial cells express functional adrenergic receptors $(135,136)$. Norepinephrine (NE) released from the sympathetic nervous system (SNS) can influence immune responses and innervate the thymus $(137,138)$. Thymus involution is associated with increased noradrenergic nerve fiber density and NE concentration, accompanied with immunosuppression in male rats and mice (139). Several studies have also shown that the effect of the SNS on thymic cell maturation and development is the outcome of multiple interactions between sympathetic and other neurotransmitters and the endocrine system, and may also depend on the immunological status of the host, under physiological conditions $(22,131,140,141)$.

The SNS is also activated in hypertension, influencing renal perfusion and oxygenation (142). In the majority of studies in humans and animal models of hypertension, drugs and interventions can reduce $\mathrm{BP}$ and prolong survival rates by activating the parasympathetic nervous system (vagal), by blocking or inhibiting the SNS and the RAS (143-149). Early studies have shown that experimental lesioning of specific circumventricular organs of the forebrain, including the subfornical organ, the anteroventral third ventricle region involving the inferior aspects of the lateral terminalis, prevents the formation of several forms of experimental high BP $(150,151)$. Increasing evidence indicates that the cardiovascular damage caused by overstimulation of the SNS and RAS, their $\alpha$ - and $\beta$-adrenergic receptors, and Ang II AT1 receptors is mediated through proinflammatory activation of the immune system (152-155).

Resistant hypertension refers to the case of patient BP remaining $>140 / 90 \mathrm{mmHg}$ following the use of a variety of antihypertensive drugs (156-158). Traditional treatments are not effective, therefore, it is necessary to develop novel therapeutic approaches, and highly selective renal denervation (RDN) is one of these approaches (159-161). RDN, a catheter-based approach developed to disrupt the renal sympathetic nerves using radiofrequency energy, is a promising therapy for resistant hypertension (142). Studies have shown that the efficacy of RDN in different models of hypertension requires examination as a method that matches the causal mechanisms of the hypertension (161-165). Reported for the first time in 2009, the ablation of renal artery denervation technology, as a sympathetic nerve and RAS activity non-drug block technique, has been successfully applied to the clinical treatment of resistant hypertension (166). In a relatively small number of patients, the first clinical study showed that this technique appeared to be safe and effective (166-168). Systolic $\mathrm{BP}$ and diastolic BP were reduced by $22 / 11$ and $27 / 17 \mathrm{mmHg}$ at 6 and 12 months post-RDN, respectively, and no serious adverse events had occurred at the follow-up at 1 year. Worthley et al (169) adopted a single electrode radiofrequency ablation catheter for RDN treatment in a prospective, multicenter, nonrandomized cohort study, which showed that the patient BP was also significantly reduced at 6 months by
26/10 $\mathrm{mmHg}$, compared with preoperative BP. The early stage of the preliminary results of transcatheter renal artery ablation treatment technology show it can safely and effectively reduce BP levels in patients with resistant hypertension. Consequently, it is suggested that RDN decreases sympathetic activity and may potentially improve renal oxygenation, resulting in altered sodium handling by the kidneys and a decrease in peripheral vascular resistance, thereby removing the trigger for hypertension.

Taken together, the ANS may be involved in the process of hypertension by regulating the function of the thymus.

\section{Aging, thymosin $\beta 4$ and hypertension}

The thymus is the main immune organ capable of generating $\mathrm{T}$ cells throughout life, and is crucial for the development, selection and maintenance of peripheral $\mathrm{T}$ cells. It is well documented that aging leads to an increase in infection and mortality rate, which has a negative impact on the immune response. Aging reduces immune function, partly due to thymic involution leading to a marked loss of progenitors, epithelial cells and differentiating thymocytes, causing a decline in the production of naïve T cells by the thymus (170-176).

The thymus transcription factor forkhead box N1 (Foxn1) is the most important factor for complete physiological function of the thymus $(174,177-179)$. With atrophy of the thymus, the expression of the thymus aging-associated gene Foxn1 decreases, which leads to the downregulation of Foxn1 with age. Increasing the expression of Foxn1 can improve the function of the thymus, and even promote regeneration of the thymus by increasing the expression of Foxn1 (180). Žuklys et al (181) reported that Foxn1 regulates the expression of genes involved in antigen processing and thymocyte selection, in addition to the transcriptional control of genes involved in the attraction and lineage commitment of $\mathrm{T}$ cell precursors. Therefore, there is evidence to suggest that the thymus Foxn1 may be involved in the process of high BP. In previous studies, the atrophy of thymus organs in hypertensive mice has been confirmed, however, the specific change in thymus function remains to be fully elucidated.

Thymosin $\beta 4$ (T $\beta 4)$, a peptide of 43 amino acids first identified by extraction from the calf thymus, is the most abundant member of the highly conserved $\beta$-thymosin family $(182,183)$. It is part of the thymosin fraction 5, a partially purified thymic preparation, which is involved in thymus-dependent lymphocyte regulation $(184,185)$. The functions of $T \beta 4$ include the involvement of thymus-dependent lymphocyte maturation and a variety of cellular processes, including cell migration, chemotaxis, maintenance of cell shape and cell division (186-189). It is well documented that $\mathrm{T} \beta 4$ can prevent inflammation and fibrosis, promoting healing in the eye, skin, and heart, and can control cell morphogenesis and motility by regulating the dynamics of the actin cytoskeleton (190-193). In addition, T $\beta 4$ can promote repair and reduce late fibrosis in kidney injury, and is increased in vascular, tubulointerstitial and myocardial fibrosis (194-199). T $\beta 4$ can also enhance endothelial cell differentiation and angiogenesis (200).

Cavasin et al found that a cytosolic enzyme prolyl oligopeptidase (POP) involved in the metabolism of several peptidic hormones and neuropeptides is widely distributed 
in the CNS, peripheral tissues and body fluids, and is responsible for the release of $\mathrm{N}$-acetyl-seryl-aspartyl-lysyl-proline (Ac-SDKP) from its precursor T $\beta 4$ (201-205). Ac-SDKP can reduce collagen deposition, and reverse inflammation and fibrosis in the heart and kidneys when it is chronically infused into rats with hypertension and myocardial infarction (206-211). In addition, decreased endogenous levels of Ac-SDKP promote organ fibrosis, including the vasculature, heart and kidneys (1,196,208,212-214). Previous studies have shown that oral administration of POP inhibitors significantly reduced endogenous levels of Ac-SDKP in the heart and kidney in normal rats, and Ac-SDKP assisted in regulating collagen protein content, through promoting collagen deposition, vascular fibrosis and glomerular sclerosis.

According to the above findings and previous studies, it appears that the expression of Ang II type 1 receptor-associated protein (ATRAP) is downregulated, due to the increase of Ang II, resulting in a decline in function of the thymus and a decrease in expression of the thymus transcription factor Foxn1, causing an imbalance of T cell subsets. ATRAP is a transmembrane protein localized in intracellular trafficking vesicles and the plasma membrane $(215,216)$. In addition, the secretion of thymosin prevents target organ damage and fibrosis, which slows or reverses the process of hypertension. T $\beta 4$ is decomposed into Ac-SDKP under the action of POP, which can reduce the damage to the target organ, ameliorating or improving BP. Based on the above, a proposed mechanism of thymic function involved in the process of hypertension has been hypothesized (Fig. 2). The change in thymus function provides a novel target for the treatment of hypertension.

\section{Conclusion and prospects}

Inflammatory and immune system mechanisms are crucial in the pathophysiology of hypertension and cardiovascular disease. T lymphocytes mature in the thymus and are important in the inflammatory response and the immune response, which can induce hypertension. The important mechanism for regulating the inflammatory response involves tissue and circulating leukocytes and macrophages. T lymphocytes are involved in the pathogenesis of hypertensive vascular remodeling. An imbalance between Tregs and $\mathrm{T}$ effector lymphocytes may be the cause of elevated BP and the progression of vascular damage.

T lymphocytes and macrophages infiltrate the kidneys in various models of hypertension. The aggregation of inflammatory factors, complement and immune response in the kidney and renal vascular injury can cause hypertension. The ANS is involved in the process of hypertension by modulating the immune response.

Based on previous studies, the changes in thymus function appear to have an effect on the process of hypertension. The proposed mechanism underlying the involvement of the thymus in the process of hypertension is as follows: Ang II may affect the function of the thymus and expression of the thymus transcription factor Foxn1 through the downregulated expression of ATRAP, and then affect the balance of T lymphocytes, which causes endothelial dysfunction and target organ damage, including fibrosis, thereby leading to hypertension.

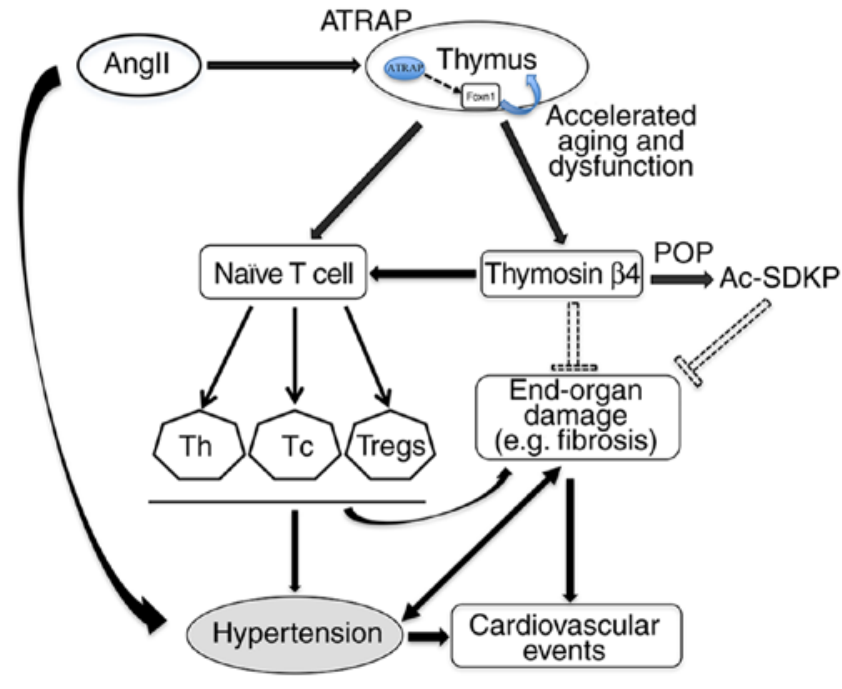

Figure 2. Role of the thymus in hypertension and target organ damage. Thymus dysfunction leads to the imbalance of $\mathrm{T}$ cell subsets and a change in the secretion of $\mathrm{T} \beta 4$, thereby aggravating the progression of hypertension and target organ damage, in addition to other cardiovascular events. T $\beta 4$, thymosin $\beta 4$; Ang II, angiotensin II; ATRAP, Ang II type 1 receptor-associated protein; Foxn1, forkhead box N1; POP, prolyl oligopeptidase; Ac-SDKP, N-acetyl-seryl-aspartyl-lysyl-proline; Th, T helper; Tc, cytotoxic T cell; Tregs, regulatory T cells.

In conclusion, novel data increasingly suggests the potential for novel targets involved in thymus function for therapeutic intervention to modify the course and reduce events in cardiovascular disease and hypertension, as evidence has increasingly implicated thymus-related mechanisms. Further investigations on the changes of thymus function are likely to assist in the development of novel therapeutic targets that may improve outcomes in hypertension and cardiovascular disease, and assist in identifying novel approaches for the treatment of hypertension and vascular disease.

\section{Acknowledgements}

Not applicable.

\section{Funding}

This study was supported by the National Natural Science Foundation of China (grant nos. 81130065, 81072981, 30971101, 31171130, 30900528 and 91539118), the Shanghai Pujiang Talent Program (D-15), the Shanghai Key Basic Research Program (grant no. 10411956500) and the Shanghai Project of International Cooperation and Exchange (grant no. 10410701700).

\section{Availability of data and materials}

Not applicable.

\section{Authors' contributions}

$\mathrm{XD}, \mathrm{ZW}$ and $\mathrm{CL}$ conceived and designed the paper. $\mathrm{XD}, \mathrm{LH}$ and YC analyzed the relevant literature. XD, JW, JL, FW, JS and $\mathrm{YZ}$ drew the figures and $\mathrm{XD}$ wrote the paper. 


\section{Ethics approval and consent to participate}

Not applicable.

\section{Consent for publication}

Not applicable.

\section{Competing interests}

The authors declare that there are no competing interests.

\section{References}

1. Cavasin MA, Liao TD, Yang XP, Yang JJ and Carretero OA Decreased endogenous levels of Ac-SDKP promote organ fibrosis. Hypertension 50: 130-136, 2007.

2. Neutel JM, Giles TD, Punzi H, Weiss RJ, Li H and Finck A Long-term safety of nebivolol and valsartan combination therapy in patients with hypertension: An open-label, single-arm, multicenter study. J Am Soc Hypertens 8: 915-920, 2014.

3. Safaeian L, Hajhashemi V, Haghjoo Javanmard S and Sanaye Naderi H: The effect of protocatechuic acid on blood pressure and oxidative stress in glucocorticoid-induced hypertension in rat. Iran J Pharm Res 15 (Suppl): S83-S91, 2016.

4. Chmielewski V, Drupt F and Morfin R: Dexamethasone-induced apoptosis of mouse thymocytes: Prevention by native 7alpha-hydroxysteroids. Immunol Cell Biol 78: 238-246, 2000.

5. Walters SN, Webster KE, Daley S and Grey ST: A role for intrathymic B cells in the generation of natural regulatory T cells. J Immunol 193: 170-176, 2014.

6. Lynch HE, Goldberg GL, Chidgey A, Van den Brink MR, Boyd R and Sempowski GD: Thymic involution and immune reconstitution. Trends Immunol 30: 366-373, 2009.

7. Murray JM, Kaufmann GR, Hodgkin PD, Lewin SR, Kelleher AD, Davenport MP and Zaunders JJ: Naive T cells are maintained by thymic output in early ages but by proliferation without phenotypic change after age twenty. Immunol Cell Biol 81: 487-495, 2003.

8. Ruan L, Zhang Z, Mu L, Burnley P, Wang L, Coder B, Zhuge Q and Su DM: Biological significance of FoxN1 gain-of-function mutations during $\mathrm{T}$ and $\mathrm{B}$ lymphopoiesis in juvenile mice. Cell Death Dis 5: e1457, 2014.

9. Fukuda S, Tsuchikura S and Iida H: Age-related changes in blood pressure, hematological values, concentrations of serum biochemical constituents and weights of organs in the SHR/Izm, SHRSP/Izm and WKY/Izm. Exp Anim 53: 67-72, 2004.

10. Rodriguez-Iturbe B and Johnson RJ: The role of renal microvascular disease and interstitial inflammation in salt-sensitive hypertension. Hypertens Res 33: 975-980, 2010.

11. Svendsen UG: The importance of thymus in the pathogenesis of the chronic phase of hypertension in mice following partial infarction of the kidney. Acta Pathol Microbiol Scand A 85: 539-547, 1977.

12. Svendsen UG: The effect of penicillamine on blood pressure and vascular disease in mice with infarct-kidney hypertension. Scand J Rheumatol 8: 81-86, 1979.

13. Svendsen UG: The role of thymus for the development and prognosis of hypertension and hypertensive vascular disease in mice following renal infarction. Acta Pathol Microbiol Scand A 84 235-243, 1976

14. Ba D, Takeichi N, Kodama T and Kobayashi H: Restoration of $\mathrm{T}$ cell depression and suppression of blood pressure in spontaneously hypertensive rats (SHR) by thymus grafts or thymus extracts. J Immunol 128: 1211-1216, 1982.

15. Bento-de-Souza L, Victor JR, Bento-de-Souza LC, Arrais-Santos M, Rangel-Santos AC, Pereira-Costa É, Raniero-Fernandes E, Seixas-Duarte MI, Oliveira-Filho JB and Silva Duarte AJ: Constitutive expression of genes encoding notch receptors and ligands in developing lymphocytes, nTreg cells and dendritic cells in the human thymus. Results Immunol 6: 15-20, 2016.

16. Plum J, De Smedt M, Leclercq G, Taghon T, Kerre T and Vandekerckhove B: Human intrathymic development: A selective approach. Semin Immunopathol 30: 411-423, 2008.
17. Hu Z, Lancaster JN and Ehrlich LI: The contribution of chemokines and migration to the induction of central tolerance in the Thymus. Front Immunol 6: 398, 2015.

18. Hu Z, Lancaster JN, Sasiponganan C and Ehrlich LI: CCR4 promotes medullary entry and thymocyte-dendritic cell interactions required for central tolerance. J Exp Med 212: 1947-1965, 2015.

19. Love PE and Bhandoola A: Signal integration and crosstalk during thymocyte migration and emigration. Nat Rev Immunol 11: 469-477, 2011.

20. Richards DM, Delacher M, Goldfarb Y, Kägebein D, Hofer AC, Abramson $\mathbf{J}$ and Feuerer $\mathrm{M}$ : Treg cell differentiation: From Thymus to peripheral tissue. Prog Mol Biol Transl Sci 136: $175-205,2015$.

21. Abbas AK, Benoist C, Bluestone JA, Campbell DJ, Ghosh S, Hori S, Jiang S, Kuchroo VK, Mathis D, Roncarolo MG, et al: Regulatory T cells: Recommendations to simplify the nomenclature. Nat Immunol 14: 307-308, 2013.

22. Bod L, Douguet L, Auffray C, Lengagne R, Bekkat F, Rondeau E, Molinier-Frenkel V, Castellano F, Richard Y and Prévost-Blondel A: IL-4-induced gene 1: A negative immune checkpoint controlling $\mathrm{B}$ cell differentiation and activation. J Immunol 200: 1027-1038, 2018.

23. McLeod JJ, Baker B and Ryan JJ: Mast cell production and response to IL-4 and IL-13. Cytokine 75: 57-61, 2015.

24. Zhang X, Voskens CJ, Sallin M, Maniar A, Montes CL, Zhang Y, Lin W, Li G, Burch E, Tan M, et al: CD137 promotes proliferation and survival of human B cells. J Immunol 184: 787-795, 2010.

25. Nilsson G and Nilsson K: Effects of interleukin (IL)-13 on immediate-early response gene expression, phenotype and differentiation of human mast cells. Comparison with IL-4. Eur J Immunol 25: 870-873, 1995.

26. Groves AM, Johnston CJ, Misra RS, Williams JP and Finkelstein JN: Effects of IL-4 on pulmonary fibrosis and the accumulation and phenotype of macrophage subpopulations following thoracic irradiation. Int J Radiat Biol 92: 754-765, 2016.

27. Francos-Quijorna I, Amo-Aparicio J, Martinez-Muriana A and López-Vales R: IL-4 drives microglia and macrophages toward a phenotype conducive for tissue repair and functional recovery after spinal cord injury. Glia 64: 2079-2092, 2016.

28. Czimmerer Z, Varga T, Kiss M, Vázquez CO, Doan-Xuan QM, Rückerl D, Tattikota SG, Yan X, Nagy ZS, Daniel B, et al: The IL-4/STAT6 signaling axis establishes a conserved microRNA signature in human and mouse macrophages regulating cell survival via miR-342-3p. Genome Med 8: 63, 2016.

29. Miossec P, Korn T and Kuchroo VK: Interleukin-17 and type 17 helper T cells. N Engl J Med 361: 888-898, 2009.

30. Veldhoen M, Hocking RJ, Atkins CJ, Locksley RM and Stockinger B: TGFbeta in the context of an inflammatory cytokine milieu supports de novo differentiation of IL-17-producing T cells. Immunity 24: 179-189, 2006.

31. Mangan PR, Harrington LE, O'Quinn DB, Helms WS, Bullard DC, Elson CO, Hatton RD, Wahl SM, Schoeb TR and Weaver CT: Transforming growth factor-beta induces development of the T(H)17 lineage. Nature 441: 231-234, 2006.

32. Ivanov II, McKenzie BS, Zhou L, Tadokoro CE, Lepelley A, Lafaille JJ, Cua DJ and Littman DR: The orphan nuclear receptor RORgammat directs the differentiation program of proinflammatory IL-17 ${ }^{+}$T helper cells. Cell 126: 1121-1133, 2006.

33. Kolls JK and Lindén A: Interleukin-17 family members and inflammation. Immunity 21: 467-476, 2004.

34. Mazidi M, Penson P, Gluba-Brzozka A, Rysz J and Banach M: Relationship between long noncoding RNAs and physiological risk factors of cardiovascular disease. J Clin Lipidol 11: 617-623, 2017.

35. Kaur J: A comprehensive review on metabolic syndrome. Cardiol Res Pract 2014: 943162, 2014

36. Ahbap E, Sakaci T, Kara E, Sahutoglu T, Koc Y, Basturk T, Sevinc M, Akgol C, Hasbal B, Isleem M, et al: Serum uric acid levels and inflammatory markers with respect to dipping status: A retrospective analysis of hypertensive patients with or without chronic kidney disease. Clin Exp Hypertens 38: 555-563, 2016.

37. Virdis A, Dell'Agnello U and Taddei S: Impact of inflammation on vascular disease in hypertension. Maturitas 78: 179-183, 2014.

38. Taddei S, Caraccio N, Virdis A, Dardano A, Versari D, Ghiadoni L, Ferrannini E, Salvetti A and Monzani F: Low-grade systemic inflammation causes endothelial dysfunction in patients with Hashimoto's thyroiditis. J Clin Endocrinol Metab 91: 5076-5082, 2006.

39. Mirsaeidi M, Omar HR, Ebrahimi G and Campos M: The association between ESR and CRP and systemic hypertension in sarcoidosis. Int J Hypertens 2016: 2402515, 2016. 
40. Hezel M, Peleli M, Liu M, Zollbrecht C, Jensen BL, Checa A Giulietti A, Wheelock CE, Lundberg JO, Weitzberg E and Carlström M: Dietary nitrate improves age-related hypertension and metabolic abnormalities in rats via modulation of angiotensin II receptor signaling and inhibition of superoxide generation. Free Radic Biol Med 99: 87-98, 2016.

41. Victorio JA, Clerici SP, Palacios R, Alonso MJ, Vassallo DV, Jaffe IZ, Rossoni LV and Davel AP: Spironolactone prevents endothelial nitric oxide synthase uncoupling and vascular dysfunction induced by $\beta$-adrenergic overstimulation: Role of perivascular adipose tissue. Hypertension 68: 726-735, 2016.

42. Goto K, Fujii K, Onaka U, Abe I and Fujishima M: Reninangiotensin system blockade improves endothelial dysfunction in hypertension. Hypertension 36: 575-580, 2000.

43. Cheng ZJ, Vaskonen T, Tikkanen I, Nurminen K, Ruskoaho H, Vapaatalo H, Muller D, Park JK, Luft FC and Mervaala EM: Endothelial dysfunction and salt-sensitive hypertension in spontaneously diabetic Goto-Kakizaki rats. Hypertension 37: 433-439, 2001

44. McIntyre M, Bohr DF and Dominiczak AF: Endothelial function in hypertension: The role of superoxide anion. Hypertension 34: 539-545, 1999.

45. Virdis A, Ghiadoni L, Plantinga Y, Taddei S and Salvetti A: C-reactive protein and hypertension: Is there a causal relationship? Curr Pharm Des 13: 1693-1698, 2007.

46. Bautista LE, Vera LM, Arenas IA and Gamarra G: Independent association between inflammatory markers (C-reactive protein, interleukin-6, and TNF-alpha) and essential hypertension. J Hum Hypertens 19: 149-154, 2005.

47. Lakoski SG, Cushman M,Palmas W, Blumenthal R,D'Agostino RB Jr and Herrington DM: The relationship between blood pressure and C-reactive protein in the multi-ethnic study of atherosclerosis (MESA). J Am Coll Cardiol 46: 1869-1874, 2005.

48. Schiffrin EL: Immune mechanisms in hypertension and vascular injury. Clin Sci (Lond) 126: 267-274, 2014

49. Blake GJ, Rifai N, Buring JE and Ridker PM: Blood pressure, C-reactive protein, and risk of future cardiovascular events. Circulation 108: 2993-2999, 2003.

50. Bermudez EA, Rifai N, Buring J, Manson JE and Ridker PM: Interrelationships among circulating interleukin-6, C-reactive protein, and traditional cardiovascular risk factors in women. Arterioscler Thromb Vasc Biol 22: 1668-1673, 2002.

51. Chae CU, Lee RT, Rifai N and Ridker PM: Blood pressure and inflammation in apparently healthy men. Hypertension 38 399-403, 2001

52. Yamada S, Gotoh T, Nakashima $\mathrm{Y}$, Kayaba K, Ishikawa $\mathrm{S}$, Nago N, Nakamura Y, Itoh Y and Kajii E: Distribution of serum C-reactive protein and its association with atherosclerotic risk factors in a Japanese population: Jichi medical school cohort study. Am J Epidemiol 153: 1183-1190, 2001

53. Ford ES and Giles WH: Serum C-reactive protein and fibrinogen concentrations and self-reported angina pectoris and myocardial infarction: Findings from national health and nutrition examination survey III. J Clin Epidemiol 53: 95-102, 2000.

54. Rohde LE, Hennekens CH and Ridker PM: Survey of C-reactive protein and cardiovascular risk factors in apparently healthy men. Am J Cardiol 84: 1018-1022, 1999.

55. Venugopal SK, Devaraj S, Yuhanna I, Shaul P and Jialal I: Demonstration that $\mathrm{C}$-reactive protein decreases eNOS expression and bioactivity in human aortic endothelial cells. Circulation 106 : 1439-1441, 2002

56. Verma S, Li SH, Badiwala MV, Weisel RD, Fedak PW, Li RK, Dhillon B and Mickle DA: Endothelin antagonism and interleukin-6 inhibition attenuate the proatherogenic effects of C-reactive protein. Circulation 105: 1890-1896, 2002.

57. Verma S, Wang CH, Li SH, Dumont AS, Fedak PW, Badiwala MV Dhillon B, Weisel RD, Li RK, Mickle DA and Stewart DJ: A self-fulfilling prophecy: C-reactive protein attenuates nitric oxide production and inhibits angiogenesis. Circulation 106 913-919, 2002

58. Romero JC and Reckelhoff JF: State-of-the-Art lecture. Role of angiotensin and oxidative stress in essential hypertension. Hypertension 34: 943-949, 1999.

59. Mervaala E, Müller DN, Schmidt F, Park JK, Gross V, Bader M, Breu V, Ganten D, Haller H and Luft FC: Blood pressureindependent effects in rats with human renin and angiotensinogen genes. Hypertension 35: 587-594, 2000.

60. Muller DN, Dechend R, Mervaala EM, Park JK, Schmidt F, Fiebeler A, Theuer J, Breu V, Ganten D, Haller H and Luft FC: NF-kappaB inhibition ameliorates angiotensin II-induced inflammatory damage in rats. Hypertension 35: 193-201, 2000.
61. Müller DN, Mervaala EM, Dechend R, Fiebeler A, Park JK, Schmidt F, Theuer J, Breu V, Mackman N, Luther T, et al: Angiotensin II (AT(1)) receptor blockade reduces vascular tissue factor in angiotensin II-induced cardiac vasculopathy. Am J Pathol 157: 111-122, 2000.

62. Ji Q, Cheng G, Ma N, Huang Y, Lin Y, Zhou Q, Que B, Dong J, Zhou Y and Nie S: Circulating Th1, Th2, and Th17 levels in hypertensive patients. Dis Markers 2017: 7146290, 2017.

63. McMaster WG, Kirabo A, Madhur MS and Harrison DG: Inflammation, immunity, and hypertensive end-organ damage. Circ Res 116: 1022-1033, 2015.

64. Madhur MS, Lob HE, McCann LA, Iwakura Y, Blinder Y, Guzik TJ and Harrison DG: Interleukin 17 promotes angiotensin II-induced hypertension and vascular dysfunction. Hypertension 55: 500-507, 2010.

65. De Ciuceis C, Rossini C, La Boria E, Porteri E, Petroboni B, Gavazzi A, Sarkar A, Rosei EA and Rizzoni D: Immune mechanisms in hypertension. High Blood Press Cardiovasc Prev 21: 227-234, 2014.

66. Dai X, Huang S, He Z, Wu F, Ding R, Chen Y, Liang C and Wu Z: Dysfunction of the thymus in mice with hypertension. Exp Ther Med 13: 1386-1392, 2017.

67. Ebringer A and Doyle AE: Raised serum IgG levels in hypertension. Br Med J 2: 146-148, 1970.

68. Leibowitz A and Schiffrin EL: Immune mechanisms in hypertension. Curr Hypertens Rep 13: 465-472, 2011.

69. Lin J, Yang L, Silva HM, Trzeciak A, Choi Y, Schwab SR, Dustin ML and Lafaille JJ: Increased generation of Foxp3(+) regulatory $\mathrm{T}$ cells by manipulating antigen presentation in the thymus. Nat Commun 7: 10562, 2016.

70. Wing K and Sakaguchi S: Regulatory T cells exert checks and balances on self tolerance and autoimmunity. Nat Immunol 11: 7-13, 2010.

71. Mellanby RJ, Thomas DC and Lamb J: Role of regulatory T-cells in autoimmunity. Clin Sci (Lond) 116: 639-649, 2009.

72. Piccirillo CA, d'Hennezel E, Sgouroudis E and Yurchenko E: $\mathrm{CD} 4^{+} \mathrm{Foxp}^{+}$regulatory $\mathrm{T}$ cells in the control of autoimmunity: In vivo veritas. Curr Opin Immunol 20: 655-662, 2008.

73. Takeichi N, Suzuki K and Kobayashi H: Characterization of immunological depression in spontaneously hypertensive rats. Eur J Immunol 11: 483-487, 1981.

74. Olsen F: Transfer of arterial hypertension by splenic cells from DOCA-salt hypertensive and renal hypertensive rats to normotensive recipients. Acta Pathol Microbiol Scand C 88: 1-5, 1980.

75. Takeichi N, Suzuki K, Okayasu T and Kobayashi H: Immunological depression in spontaneously hypertensive rats. Clin Exp Immunol 40: 120-126, 1980.

76. Svendsen UG: Evidence for an initial, thymus independent and a chronic, thymus dependent phase of DOCA and salt hypertension in mice. Acta Pathol Microbiol Scand A 84: 523-528, 1976.

77. Marvar PJ, Vinh A, Thabet S, Lob HE, Geem D, Ressler KJ and Harrison DG: T lymphocytes and vascular inflammation contribute to stress-dependent hypertension. Biol Psychiatry 71: 774-782, 2012.

78. Harrison DG, Guzik TJ, Lob HE, Madhur MS, Marvar PJ, Thabet SR, Vinh A and Weyand CM: Inflammation, immunity, and hypertension. Hypertension 57: 132-140, 2011.

79. Muller DN, Kvakan H and Luft FC: Immune-related effects in hypertension and target-organ damage. Curr Opin Nephrol Hypertens 20: 113-117, 2011.

80. Calame DG, Mueller-Ortiz SL and Wetsel RA: Innate and adaptive immunologic functions of complement in the host response to Listeria monocytogenes infection. Immunobiology 221: 1407-1417, 2016

81. D'Alincourt Salazar M, Manuel ER, Tsai W, D'Apuzzo M, Goldstein L, Blazar BR and Diamond DJ: Evaluation of innate and adaptive immunity contributing to the antitumor effects of PD1 blockade in an orthotopic murine model of pancreatic cancer. Oncoimmunology 5: e1160184, 2016.

82. Weyd H: More than just innate affairs-on the role of annexins in adaptive immunity. Biol Chem 397: 1017-1029, 2016

83. Kvakan H, Luft FC and Muller DN: Role of the immune system in hypertensive target organ damage. Trends Cardiovasc Med 19: 242-246, 2009.

84. Vergaro G, Prud'homme M, Fazal L, Merval R, Passino C, Emdin M, Samuel JL, Cohen Solal A and Delcayre C: Inhibition of Galectin-3 pathway prevents isoproterenol-induced left ventricular dysfunction and fibrosis in mice. Hypertension 67: 606-612, 2016 
85. Wenzel U, Turner JE, Krebs C, Kurts C, Harrison DG and Ehmke H: Immune mechanisms in arterial hypertension. J Am Soc Nephrol 27: 677-686, 2016.

86. Harrison DG: The immune system in hypertension. Trans Am Clin Climatol Assoc 125: 130-140, 2014

87. Kossmann S, Hu H, Steven S, Schönfelder T, Fraccarollo D, Mikhed Y, Brahler M, Knorr M, Brandt M, Karbach SH, et al Inflammatory monocytes determine endothelial nitric-oxide synthase uncoupling and nitro-oxidative stress induced by angiotensin II. J Biol Chem 289: 27540-27550, 2014.

88. Liu J, Yang F, Yang XP, Jankowski M and Pagano PJ: NAD(P)H oxidase mediates angiotensin II-induced vascular macrophage infiltration and medial hypertrophy. Arterioscler Thromb Vasc Biol 23: 776-782, 2003.

89. Wenzel P, Knorr M, Kossmann S, Stratmann J, Hausding M, Schuhmacher S, Karbach SH, Schwenk M, Yogev N, Schulz E, et al: Lysozyme M-positive monocytes mediate angiotensin II-induced arterial hypertension and vascular dysfunction. Circulation 124: 1370-1381, 2011.

90. Ko EA, Amiri F, Pandey NR, Javeshghani D, Leibovitz E, Touyz RM and Schiffrin EL: Resistance artery remodeling in deoxycorticosterone acetate-salt hypertension is dependent on vascular inflammation: Evidence from m-CSF-deficient mice. Am J Physiol Heart Circ Physiol 292: H1789-H1795, 2007.

91. De Ciuceis C, Amiri F, Brassard P, Endemann DH, Touyz RM and Schiffrin EL: Reduced vascular remodeling, endothelial dysfunction, and oxidative stress in resistance arteries of angiotensin II-infused macrophage colony-stimulating factor-deficient mice: Evidence for a role in inflammation in angiotensin-induced vascular injury. Arterioscler Thromb Vasc Biol 25: 2106-2113, 2005.

92. Abais-Battad JM, Rudemiller NP and Mattson DL: Hypertension and immunity: Mechanisms of T cell activation and pathways of hypertension. Curr Opin Nephrol Hypertens 24: 470-474, 2015.

93. Schiffrin EL: The immune system: Role in hypertension. Can J Cardiol 29: 543-548, 2013

94. Verlohren S, Muller DN, Luft FC and Dechend R: Immunology in hypertension, preeclampsia, and target-organ damage. Hypertension 54: 439-443, 2009.

95. Idris-Khodja N, Mian MO, Paradis P and Schiffrin EL: Dual opposing roles of adaptive immunity in hypertension. Eur Heart J 35: 1238-1244, 2014.

96. Guzik TJ, Hoch NE, Brown KA, McCann LA, Rahman A, Dikalov S, Goronzy J, Weyand C and Harrison DG: Role of the $\mathrm{T}$ cell in the genesis of angiotensin II induced hypertension and vascular dysfunction. J Exp Med 204: 2449-2460, 2007.

97. Zhang W and Victor RG: Calcineurin inhibitors cause renal afferent activation in rats: A novel mechanism of cyclosporine-induced hypertension. Am J Hypertens 13: 999-1004, 2000

98. Rodríguez-Iturbe B, Pons H, Quiroz Y, Gordon K, Rincón J, Chávez M, Parra G, Herrera-Acosta J, Gómez-Garre D, Largo R, et al: Mycophenolate mofetil prevents salt-sensitive hypertension resulting from angiotensin II exposure. Kidney Int 59: 2222-2232, 2001

99. Crowley SD, Frey CW, Gould SK, Griffiths R, Ruiz P, Burchette JL, Howell DN, Makhanova N, Yan M, Kim HS, et al: Stimulation of lymphocyte responses by angiotensin II promotes kidney injury in hypertension. Am J Physiol Renal Physiol 295: F515-F524, 2008.

100. Wei Z, Spizzo I, Diep H, Drummond GR, Widdop RE and Vinh A Differential phenotypes of tissue-infiltrating $\mathrm{T}$ cells during angiotensin II-induced hypertension in mice. PLoS One 9: e114895, 2014

101. Rosenthal AS: Regulation of the immune response-role of the macrophage. N Engl J Med 303: 1153-1156, 1980.

102. Gordon S: The role of the macrophage in immune regulation Res Immunol 149: 685-688, 1998

103. Lam RS, O'Brien-Simpson NM, Holden JA, Lenzo JC, Fong SB and Reynolds EC: Unprimed, M1 and M2 macrophages differentially interact with porphyromonas gingivalis. PLoS One 11: e0158629, 2016

104. Mellman I and Steinman RM: Dendritic cells: Specialized and regulated antigen processing machines. Cell 106: 255-258, 2001

105. Goldschneider I and Cone RE: A central role for peripheral dendritic cells in the induction of acquired thymic tolerance. Trends Immunol 24: 77-81, 2003.

106. Oh J and Shin JS: The role of dendritic cells in central tolerance. Immune Netw 15: 111-120, 2015.

107. Gelosa P, Pignieri A, Gianazza E, Criniti S, Guerrini U, Cappellini MD, Banfi C, Tremoli E and Sironi L: Altered iron homeostasis in an animal model of hypertensive nephropathy: Stroke-prone rats. J Hypertens 31: 2259-2269, 2013.
108. Singh MV, Chapleau MW, Harwani SC and Abboud FM: The immune system and hypertension. Immunol Res 59: 243-253, 2014.

109. Rudemiller N, Lund H, Jacob HJ, Geurts AM and Mattson DL; PhysGen Knockout Program: CD247 modulates blood pressure by altering T-lymphocyte infiltration in the kidney. Hypertension 63: 559-564, 2014

110. Luft FC, Dechend R and Muller DN: Immune mechanisms in angiotensin II-induced target-organ damage. Ann Med 44 (Suppl 1): S49-S54, 2012

111. Rodríguez-Iturbe B, Franco M, Tapia E, Quiroz Y and Johnson RJ: Renal inflammation, autoimmunity and salt-sensitive hypertension. Clin Exp Pharmacol Physiol 39: 96-103, 2012

112. Moon JY: Recent update of renin-angiotensin-aldosterone system in the pathogenesis of hypertension. Electrolyte Blood Press 11 $41-45,2013$

113. White FN and Grollman A: Autoimmune factors associated with infarction of the kidney. Nephron 1: 93-102, 1964.

114. Rodríguez-Iturbe B, Quiroz Y, Ferrebuz A, Parra G and Vaziri ND: Evolution of renal interstitial inflammation and NF-kappaB activation in spontaneously hypertensive rats. Am J Nephrol 24: 587-594, 2004

115. Rodríguez-Iturbe B, Ferrebuz A, Vanegas V, Quiroz Y, Mezzano S and Vaziri ND: Early and sustained inhibition of nuclear factor-kappaB prevents hypertension in spontaneously hypertensive rats. J Pharmacol Exp Ther 315: 51-57, 2005.

116. Marvar PJ, Gordon FJ and Harrison DG: Blood pressure control: Salt gets under your skin. Nat Med 15: 487-488, 2009.

117. Crowley SD, Song YS, Lin EE, Griffiths R, Kim HS and Ruiz P: Lymphocyte responses exacerbate angiotensin II-dependent hypertension. Am J Physiol Regul Integr Comp Physiol 298. R1089-R1097, 2010.

118. De Miguel C, Das S, Lund H and Mattson DL: T lymphocytes mediate hypertension and kidney damage in Dahl salt-sensitive rats. Am J Physiol Regul Integr Comp Physiol 298: R1136-R1142, 2010.

119. Yang T, Zollbrecht C, Winerdal ME, Zhuge Z, Zhang XM, Terrando N, Checa A, Sällström J, Wheelock CE, Winqvist $\mathrm{O}$, et al: Genetic abrogation of adenosine $\mathrm{A} 3$ receptor prevents uninephrectomy and high salt-induced hypertension. J Am Heart Assoc 5: e003868, 2016.

120. Dong L, Nordlohne J, Ge S, Hertel B, Melk A, Rong S, Haller H and von Vietinghoff S: T Cell CX3CR1 Mediates excess atherosclerotic inflammation in renal impairment. J Am Soc Nephrol 27: 1753-1764, 2016

121. Lucchini M, Fifer WP, Sahni R and Signorini MG: Novel heart rate parameters for the assessment of autonomic nervous system function in premature infants. Physiol Meas 37: 1436-1446, 2016.

122. Reijman S, Bakermans-Kranenburg MJ, Hiraoka R, Crouch JL, Milner JS, Alink LR and van IJzendoorn MH: Baseline functioning and stress reactivity in maltreating parents and at-risk adults: Review and meta-analyses of autonomic nervous system studies. Child Maltreat: 1077559516659937, 2016.

123. Olofsson PS, Rosas-Ballina M, Levine YA and Tracey KJ: Rethinking inflammation: Neural circuits in the regulation of immunity. Immunol Rev 248: 188-204, 2012

124. Marvar PJ, Thabet SR, Guzik TJ, Lob HE, McCann LA, Weyand C, Gordon FJ and Harrison DG: Central and peripheral mechanisms of T-lymphocyte activation and vascular inflammation produced by angiotensin II-induced hypertension. Circ Res 107: 263-270, 2010.

125. Ganta CK, Lu N, Helwig BG, Blecha F, Ganta RR, Zheng L, Ross CR, Musch TI, Fels RJ and Kenney MJ: Central angiotensin II-enhanced splenic cytokine gene expression is mediated by the sympathetic nervous system. Am J Physiol Heart Circ Physiol 289: H1683-H1691, 2005.

126. Borovikova LV, Ivanova S, Zhang M, Yang H, Botchkina GI, Watkins LR, Wang H, Abumrad N, Eaton JW and Tracey KJ: Vagus nerve stimulation attenuates the systemic inflammatory response to endotoxin. Nature 405: 458-462, 2000.

127. Ader R, Felten D and Cohen N: Interactions between the brain and the immune system. Annu Rev Pharmacol Toxicol 30 561-602, 1990

128. Bulloch K and Pomerantz W: Autonomic nervous system innervation of thymic-related lymphoid tissue in wildtype and nude mice. J Comp Neurol 228: 57-68, 1984.

129. Nance DM, Hopkins DA and Bieger D: Re-investigation of the innervation of the thymus gland in mice and rats. Brain Behav Immun 1: 134-147, 1987 
130. Tollefson L and Bulloch K: Dual-label retrograde transport: CNS innervation of the mouse thymus distinct from other mediastinum viscera. J Neurosci Res 25: 20-28, 1990.

131. Roggero E, Besedovsky HO and del Rey A: The role of the sympathetic nervous system in the thymus in health and disease. Neuroimmunomodulation 18: 339-349, 2011.

132. Winklewski PJ, Radkowski M and Demkow U: Relevance of immune-sympathetic nervous system interplay for the development of hypertension. Adv Exp Med Biol 884: 37-43, 2016.

133. Pongratz G and Straub RH: The sympathetic nervous response in inflammation. Arthritis Res Ther 16: 504, 2014.

134. Fisher JP and Paton JF: The sympathetic nervous system and blood pressure in humans: Implications for hypertension. J Hum Hypertens 26: 463-475, 2012.

135. Cupić V, Colić M, Jandrić D, Milojković B and Varagić VM: Xylazine, an alpha 2-adrenergic agonist, induces apoptosis of rat thymocytes and a thymocyte hybridoma line in vitro. Methods Find Exp Clin Pharmacol 25: 5-10, 2003.

136. Trotter RN, Stornetta RL, Guyenet PG and Roberts MR: Transneuronal mapping of the CNS network controlling sympathetic outflow to the rat thymus. Auton Neurosci 131: 9-20, 2007.

137. Elenkov IJ, Wilder RL, Chrousos GP and Vizi ES: The sympathetic nerve-an integrative interface between two supersystems: The brain and the immune system. Pharmacol Rev 52: 595-638, 2000.

138. Vizi ES, Orsó E, Osipenko ON, Haskó G and Elenkov IJ Neurochemical, electrophysiological and immunocytochemical evidence for a noradrenergic link between the sympathetic nervous system and thymocytes. Neuroscience 68: 1263-1276, 1995.

139. ThyagaRajan S, Madden KS, Teruya B, Stevens SY, Felten DL and Bellinger DL: Age-associated alterations in sympathetic noradrenergic innervation of primary and secondary lymphoid organs in female Fischer 344 rats. J Neuroimmunol 233: 54-64, 2011.

140. Leposavić G, Ugresić N, Pejcić-Karapetrović B and Mićić M: Castration of sexually immature rats affects sympathetic innervation of the adult thymus. Neuroimmunomodulation 7: 59-67, 2000

141. Leposavić G, Mićić M, Ugresić N, Bogojević M and Isaković K: Components of sympathetic innervation of the rat thymus during late fetal and postnatal development: Histofluorescence and biochemical study. Sympathetic innervation of the rat thymus. Thymus 19: 77-87, 1992.

142. Vink EE, Boer A, Verloop WL, Spiering W, Voskuil M, Vonken E, Hoogduin JM, Leiner T, Bots ML and Blankestijn PJ: The effect of renal denervation on kidney oxygenation as determined by BOLD MRI in patients with hypertension. Eur Radiol 25: 1984-1992, 2015

143. Abboud FM, Harwani SC and Chapleau MW: Autonomic neural regulation of the immune system: Implications for hypertension and cardiovascular disease. Hypertension 59: 755-762, 2012

144. Heran BS, Galm BP and Wright JM: Blood pressure lowering efficacy of alpha blockers for primary hypertension. Cochrane Database Syst Rev: CD004643, 2012

145. Esler M: The sympathetic nervous system through the ages: From Thomas Willis to resistant hypertension. Exp Physiol 96 : 611-622, 2011.

146. Frishman WH and Saunders E: $\beta$-adrenergic blockers. J Clin Hypertens (Greenwich) 13: 649-653, 2011.

147. Abboud FM: The Walter B. Cannon Memorial Award Lecture, 2009. Physiology in perspective: The wisdom of the body. In search of autonomic balance: The good, the bad, and the ugly. Am J Physiol Regul Integr Comp Physiol 298: R1449-R1467, 2010.

148. Zucker IH, Hackley JF, Cornish KG, Hiser BA, Anderson NR, Kieval R, Irwin ED, Serdar DJ, Peuler JD and Rossing MA Chronic baroreceptor activation enhances survival in dogs with pacing-induced heart failure. Hypertension 50: 904-910, 2007

149. Li M,Zheng C, Sato T, Kawada T, Sugimachi M and Sunagawa K Vagal nerve stimulation markedly improves long-term survival after chronic heart failure in rats. Circulation 109: 120-124, 2004.

150. Hering D and Schlaich M: The role of central nervous system mechanisms in resistant hypertension. Curr Hypertens Rep 17: $58,2015$.

151. Brody MJ, Varner KJ, Vasquez EC and Lewis SJ: Central nervous system and the pathogenesis of hypertension. Sites and mechanisms. Hypertension 18 (Suppl 5): IIII-III12, 1991.
152. Zubcevic J, Waki H, Raizada MK and Paton JF: Autonomicimmune-vascular interaction: An emerging concept for neurogenic hypertension. Hypertension 57: 1026-1033, 2011.

153. Raizada MK and Paton JF: Recent advances in the reninangiotensin system: Angiotensin-converting enzyme 2 and (pro) renin receptor. Exp Physiol 93: 517-518, 2008

154. Wyss JM: The role of the sympathetic nervous system in hypertension. Curr Opin Nephrol Hypertens 2: 265-273, 1993.

155. Felder RB, Francis J, Zhang ZH, Wei SG, Weiss RM and Johnson AK: Heart failure and the brain: New perspectives. Am J Physiol Regul Integr Comp Physiol 284: R259-R276, 2003.

156. Eikelis N, Hering D, Marusic P, Walton A, Lambert E, Krum H, Lambert G, Esler M and Schlaich M: [Op.7d.10] The effect of renal denervation on adipokines in patients with resistant hypertension. J Hypertens 34 (Suppl 2): e97, 2016.

157. Rosa J, Widimsky P, Waldauf P, Lambert L, Zelinka T, Taborsky M, Branny M, Tousek P, Petrak O, Curila K, et al: [Op.7d.09] the role of adding spironolactone and renal denervation in true resistant hypertension. One-year outcomes of randomized prague-15 study. J Hypertens 34 (Suppl 2): e96-e97, 2016.

158. Rosa J, Widimský P, Waldauf P, Lambert L, Zelinka T, Táborský M, Branny M, Toušek P, Petrák O, Čurila K, et al: Role of adding spironolactone and renal denervation in true resistant hypertension: One-year outcomes of randomized PRAGUE-15 study. Hypertension 67: 397-403, 2016.

159. Calhoun DA: Spironolactone versus renal nerve denervation for treatment of uncontrolled resistant hypertension. J Hypertens 34 : 1701-1703, 2016

160. Qi XY, Cheng B, Li YL and Wang YF: Renal denervation, adjusted drugs, or combined therapy for resistant hypertension: A meta-regression. Medicine (Baltimore) 95: e3939, 2016

161. Esler M: Renal denervation for treatment of drug-resistant hypertension. Trends Cardiovasc Med 25: 107-115, 2015.

162. Esler MD, Krum H, Schlaich M, Schmieder RE, Böhm M and Sobotka PA; Symplicity HTN-2 Investigators: Renal sympathetic denervation for treatment of drug-resistant hypertension: One-year results from the Symplicity HTN-2 randomized, controlled trial. Circulation 126: 2976-2982, 2012.

163. Fink GD and Osborn JW: Renal nerves: Time for reassessment of their role in hypertension? Am J Hypertens 27: 1245-1247, 2014.

164. Kandzari DE, Bhatt DL, Brar S, Devireddy CM, Esler M, Fahy M, Flack JM, Katzen BT, Lea J, Lee DP, et al: Predictors of blood pressure response in the SYMPLICITY HTN-3 trial. Eur Heart J 36: 219-227, 2015.

165. Schlaich MP, Esler MD, Fink GD, Osborn JW and Euler DE: Targeting the sympathetic nervous system: Critical issues in patient selection, efficacy, and safety of renal denervation. Hypertension 63: 426-432, 2014

166. Krum H, Schlaich M, Whitbourn R, Sobotka PA, Sadowski J, Bartus K, Kapelak B, Walton A, Sievert H, Thambar S, et al: Catheter-based renal sympathetic denervation for resistant hypertension: A multicentre safety and proof-of-principle cohort study. Lancet 373: 1275-1281, 2009.

167. Symplicity HTN-2 Investigators, Esler MD, Krum H, Sobotka PA, Schlaich MP, Schmieder RE and Böhm M: Renal sympathetic denervation in patients with treatment-resistant hypertension (The Symplicity HTN-2 Trial): A randomised controlled trial. Lancet 376: 1903-1909, 2010.

168. Symplicity HTN-1 Investigators: Catheter-based renal sympathetic denervation for resistant hypertension: Durability of blood pressure reduction out to 24 months. Hypertension 57: 911-917, 2011

169. Worthley SG, Tsioufis CP, Worthley MI, Sinhal A, Chew DP, Meredith IT, Malaiapan Y and Papademetriou V: Safety and efficacy of a multi-electrode renal sympathetic denervation system in resistant hypertension: The EnligHTN I trial. Eur Heart J 34: 2132-2140, 2013

170. Guo J, Feng Y, Barnes P, Huang FF, Idell S, Su DM and Shams H: Deletion of FoxN1 in the thymic medullary epithelium reduces peripheral $\mathrm{T}$ cell responses to infection and mimics changes of aging. PLoS One 7: e34681, 2012.

171. Chidgey A, Dudakov J, Seach N and Boyd R: Impact of niche aging on thymic regeneration and immune reconstitution. Semin Immunol 19: 331-340, 2007.

172. Taub DD and Longo DL: Insights into thymic aging and regeneration. Immunol Rev 205: 72-93, 2005. 
173. Fry TJ and Mackall CL: Current concepts of thymic aging. Springer Semin Immunopathol 24: 7-22, 2002.

174. Zook EC, Krishack PA, Zhang S, Zeleznik-Le NJ, Firulli AB, Witte PL and Le PT: Overexpression of Foxn1 attenuates age-associated thymic involution and prevents the expansion of peripheral CD4 memory T cells. Blood 118: 5723-5731, 2011.

175. Swain S, Clise-Dwyer K and Haynes L: Homeostasis and the age-associated defect of CD4 T cells. Semin Immunol 17: 370-377, 2005.

176. Haynes BF, Markert ML, Sempowski GD, Patel DD and Hale LP: The role of the thymus in immune reconstitution in aging, bone marrow transplantation, and HIV-1 infection. Annu Rev Immunol 18: 529-560, 2000.

177. Stutman O and Good RA: Duration of thymic function. Ser Haematol 7: 505-523, 1974.

178. Thoman ML: The pattern of T lymphocyte differentiation is altered during thymic involution. Mech Ageing Dev 82: 155-170, 1995.

179. Ortman CL, Dittmar KA, Witte PL and Le PT: Molecular characterization of the mouse involuted thymus: Aberrations in expression of transcription regulators in thymocyte and epithelial compartments. Int Immunol 14: 813-822, 2002.

180. Bredenkamp N, Nowell CS and Blackburn CC: Regeneration of the aged thymus by a single transcription factor. Development 141 $1627-1637,2014$

181. Žuklys S, Handel A, Zhanybekova S, Govani F, Keller M, Maio S, Mayer CE, Teh HY, Hafen K, Gallone G, et al: Foxn1 regulates key target genes essential for $\mathrm{T}$ cell development in postnatal thymic epithelial cells. Nat Immunol 17: 1206-1215, 2016.

182. Kim J, Wang S, Hyun J, Choi SS, Cha H, Ock M and Jung Y: Hepatic stellate cells express thymosin Beta 4 in chronically damaged liver. PLoS One 10: e0122758, 2015.

183. Paulussen M, Landuyt B, Schoofs L, Luyten W and Arckens L: Thymosin beta 4 mRNA and peptide expression in phagocytic cells of different mouse tissues. Peptides 30: 1822-1832, 2009.

184. Low TL and Goldstein AL: Chemical characterization of thymosin beta 4. J Biol Chem 257: 1000-1006, 1982.

185. Low TL, Hu SK and Goldstein AL: Complete amino acid sequence of bovine thymosin beta 4 : A thymic hormone that induces terminal deoxynucleotidyl transferase activity in thymocyte populations. Proc Natl Acad Sci USA 78: 1162-1166, 1981.

186. Dedova IV, Nikolaeva OP, Safer D, De La Cruz EM and dos Remedios CG: Thymosin beta4 induces a conformational change in actin monomers. Biophys J 90: 985-992, 2006.

187. Ballweber E, Hannappel E, Huff T, Stephan H, Haener M, Taschner N,Stoffler D, Aebi U and MannherzHG: Polymerisation of chemically cross-linked actin: Thymosin beta(4) complex to filamentous actin: Alteration in helical parameters and visualisation of thymosin beta(4) binding on F-actin. J Mol Biol 315 613-625, 2002.

188. Safer D, Elzinga M and Nachmias VT: Thymosin beta 4 and Fx, an actin-sequestering peptide, are indistinguishable. J Biol Chem 266: 4029-4032, 1991.

189. Pearse G: Normal structure, function and histology of the thymus. Toxicol Pathol 34: 504-514, 2006.

190. Bock-Marquette I, Saxena A, White MD, Dimaio JM and Srivastava D: Thymosin beta4 activates integrin-linked kinase and promotes cardiac cell migration, survival and cardiac repair. Nature 432: 466-472, 2004

191. Sosne G, Szliter EA, Barrett R, Kernacki KA, Kleinman H and Hazlett LD: Thymosin beta 4 promotes corneal wound healing and decreases inflammation in vivo following alkali injury. Exp Eye Res 74: 293-299, 2002.

192. Malinda KM, Sidhu GS, Mani H, Banaudha K, Maheshwari RK, Goldstein AL and Kleinman HK: Thymosin beta4 accelerates wound healing. J Invest Dermatol 113: 364-368, 1999.

193. Goldstein AL, Hannappel E and Kleinman HK: Thymosin beta4: Actin-sequestering protein moonlights to repair injured tissues. Trends Mol Med 11: 421-429, 2005.

194. Xu BJ, Shyr Y, Liang X, Ma LJ, Donnert EM, Roberts JD, Zhang X, Kon V, Brown NJ, Caprioli RM and Fogo AB: Proteomic patterns and prediction of glomerulosclerosis and its mechanisms. J Am Soc Nephrol 16: 2967-2975, 2005.

195. Vasilopoulou E, Winyard PJ, Riley PR and Long DA: The role of thymosin- $\beta 4$ in kidney disease. Expert Opin Biol Ther 15 (Suppl 1): S187-S190, 2015.

196. Zuo Y, Chun B, Potthoff SA, Kazi N, Brolin TJ, Orhan D, Yang HC, Ma LJ, Kon V, Myöhänen T, et al: Thymosin $\beta 4$ and its degradation product, Ac-SDKP, are novel reparative factors in renal fibrosis. Kidney Int 84: 1166-1175, 2013.
197. Ghosh AK, Murphy SB, Kishore R and Vaughan DE: Global gene expression profiling in PAI-1 knockout murine heart and kidney: Molecular basis of cardiac-selective fibrosis. PLoS One 8: e63825, 2013.

198. Ma LJ and Fogo AB: PAI-1 and kidney fibrosis. Front Biosci (Landmark Ed) 14: 2028-2041, 2009

199. Smart N, Risebro CA, Melville AA, Moses K, Schwartz RJ, Chien KR and Riley PR: Thymosin beta4 induces adult epicardial progenitor mobilization and neovascularization. Nature 445: 177-182, 2007.

200.Grant DS, Rose W, Yaen C, Goldstein A, Martinez J and Kleinman H: Thymosin beta4 enhances endothelial cell differentiation and angiogenesis. Angiogenesis 3: 125-135, 1999.

201. Liao TD, Yang XP, D'Ambrosio M, Zhang Y, Rhaleb NE and Carretero OA: N-acetyl-seryl-aspartyl-lysyl-proline attenuates renal injury and dysfunction in hypertensive rats with reduced renal mass: Council for high blood pressure research. Hypertension 55: 459-467, 2010

202. Cavasin MA, Rhaleb NE, Yang XP and Carretero OA: Proly oligopeptidase is involved in release of the antifibrotic peptide Ac-SDKP. Hypertension 43: 1140-1145, 2004.

203. Myöhänen TT, Tenorio-Laranga J, Jokinen B, VázquezSánchez R, Moreno-Baylach MJ, García-Horsman JA and Männistö PT: Prolyl oligopeptidase induces angiogenesis both in vitro and in vivo in a novel regulatory manner. $\mathrm{Br} \mathrm{J}$ Pharmacol 163: 1666-1678, 2011.

204. García-Horsman JA, Männistö PT and Venäläinen JI: On the role of prolyl oligopeptidase in health and disease. Neuropeptides 41 $1-24,2007$

205. Myöhänen TT, García-Horsman JA, Tenorio-Laranga J and Männistö PT: Issues about the physiological functions of prolyl oligopeptidase based on its discordant spatial association with substrates and inconsistencies among mRNA, protein levels, and enzymatic activity. J Histochem Cytochem 57: 831-848, 2009.

206. Shibuya K, Kanasaki K, Isono M, Sato H, Omata M, Sugimoto T, Araki S, Isshiki K, Kashiwagi A, Haneda M and Koya D: N-ace tyl-seryl-aspartyl-lysyl-proline prevents renal insufficiency and mesangial matrix expansion in diabetic $\mathrm{db} / \mathrm{db}$ mice. Diabetes 54: 838-845, 2005

207. Cingolani OH, Yang XP, Liu YH, Villanueva M, Rhaleb NE and Carretero OA: Reduction of cardiac fibrosis decreases systolic performance without affecting diastolic function in hypertensive rats. Hypertension 43: 1067-1073, 2004

208. Yang F, Yang XP, Liu YH, Xu J, Cingolani O, Rhaleb NE and Carretero OA: Ac-SDKP reverses inflammation and fibrosis in rats with heart failure after myocardial infarction. Hypertension 43: 229-236, 2004.

209. Peng H, Carretero OA, Brigstock DR, Oja-Tebbe $\mathrm{N}$ and Rhaleb NE: Ac-SDKP reverses cardiac fibrosis in rats with renovascular hypertension. Hypertension 42: 1164-1170, 2003.

210. Pradelles P, Frobert Y, Creminon C, Liozon E, Massé A and Frindel E: Negative regulator of pluripotent hematopoietic stem cell proliferation in human white blood cells and plasma as analysed by enzyme immunoassay. Biochem Biophys Res Commun 170: 986-993, 1990.

211. Pradelles P, Frobert Y, Créminon C, Ivonine $\mathrm{H}$ and Frindel $\mathrm{E}$ : Distribution of a negative regulator of haematopoietic stem cell proliferation (AcSDKP) and thymosin beta 4 in mouse tissues. FEBS Lett 289: 171-175, 1991.

212. Hrenak J, Paulis L and Simko F: N-acetyl-seryl-aspartyl-lysy 1-proline (Ac-SDKP): Potential target molecule in research of heart, kidney and brain. Curr Pharm Des 21: 5135-5143, 2015.

213. Worou ME, Liao TD, D'Ambrosio M, Nakagawa P, Janic B, Peterson EL, Rhaleb NE and Carretero OA: Renal protective effect of N-acetyl-seryl-aspartyl-lysyl-proline in dahl salt-sensitive rats. Hypertension 66: 816-822, 2015.

214. Omata M, Taniguchi H, Koya D, Kanasaki K, Sho R, Kato Y, Kojima R, Haneda M and Inomata N: N-acetyl-seryl-aspartyllysyl-proline ameliorates the progression of renal dysfunction and fibrosis in WKY rats with established anti-glomerular basement membrane nephritis. J Am Soc Nephrol 17: 674-685, 2006.

215. Lopez-Ilasaca M, Liu X, Tamura K and Dzau VJ: The angiotensin II type I receptor-associated protein, ATRAP, is a transmembrane protein and a modulator of angiotensin II signaling. Mol Biol Cell 14: 5038-5050, 2003

216. Daviet L, Lehtonen JY, Tamura K, Griese DP, Horiuchi M and Dzau VJ: Cloning and characterization of ATRAP, a novel protein that interacts with the angiotensin II type 1 receptor. J Biol Chem 274: 17058-17062, 1999.

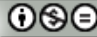

This work is licensed under a Creative Commons Attribution-NonCommercial-NoDerivatives 4.0 International (CC BY-NC-ND 4.0) License. 